BULLETIN OF PNRPU. GEOLOGY. OIL \& GAS ENGINEERING \& MINING ВЕСТНИК ПНИПУ. ГЕОЛОГИЯ. НЕФТЕГАЗОВОЕ И ГОРНОЕ ДЕЛО

ISSN 2224-9923

Volume / TOM 15 №19 2016

http://vestnik.pstu.ru/geo

УДК 622.276.6

Article / Статья

(C) PNRPU / ПНИПУ, 2016

\title{
FULL-SIZE CORE EPOCH AT LABORATORY RESEARCH OF EOR TECHNOLOGIES
}

\section{I.S. Putilov, P.N. Rekhachev, I.P. Gurbatova, N.N. Barkovskii, O.I. lakimov, O.A. Moroziuk ${ }^{1}$}

PermNIPIneft branch of LUKOIL-Engineering LLC in Perm (9 Geroev Khasana st., Building A., Perm, 614066, Russian Federation)

${ }^{1}$ Ukhta State Technical University (13 Pervomaiskaia st., Ukhta, Republic of Komi, Russian Federation)

\section{ЭПОХА ПОЛНОРАЗМЕРНОГО КЕРНА ПРИ ЛАБОРАТОРНЫХ ИССЛЕДОВАНИЯХ ТЕХНОЛОГИЙ ПОВЫШЕНИЯ НЕФТЕОТДАЧИ ПЛАСТОВ}

\section{И.С. Путилов, П.Н. Рехачев, И.П. Гурбатова, Н.Н. Барковский, О.И. Якимов, О.А. Морозюк ${ }^{1}$}

Филиал ООО «ЛУКОЙЛ-Инжиниринг» «ПермНИПИнефть» в г. Перми (614010, Россия, г. Пермь, ул. Героев Хасана, 9а)

${ }^{1}$ Ухтинский государственный технический университет (169300, Россия, Республика Коми, г. Ухта, ул. Первомайская, 13)

Received / Получена: 19.01.2016. Aсcерted / Принята: 05.05.2016. Published / Опубликована: 30.06.2016

Key words:

full-size core sample, complex carbonate reservoir, anisotropy, oil recovery factor, pilot project
Ключевые слова:

полноразмерный керновый образец, сложнопостроенный карбонатный коллектор, анизотропия, коэффициент вытеснения нефти, опытно-промышленные работы.
The article analyzes influence of core sample size on authenticity of data, obtained in laboratory simulation of reservoir stimulation technologies depending on reservoir type.

It is found that in contrast to composite models, a full-size core reflects relationship of pore systems of complex reservoirs to the full extend. That allows making more correct conclusions about the effectiveness of technologies. In particular determination of adsorption and mechanical destruction of polymer compositions, strength of created water-proof barrier, dynamics of pressure during mixture injection etc. In order to improve authenticity of results obtained in laboratory simulation at the stage of selection of full-size core samples rock anisotropy, which is common for carbonate reservoirs and are tion at the stage of selection of full-size core samples rock anisotropy, whi
usually connected to rocks fracture system, have to be taken into account.

usually connected to rocks fracture system, have to be taken into account. On the basis of ideas about improved efficiency of modeling technologies for enhanced oil recovery (EOR) for the condi-
tions of complex carbonate reservoirs laboratory study is performed. The study used core samples with thermo reversible polymer composition METKA, developed by the Institute of Petroleum Chemistry of Siberian Branch of the Russian Academy of Science. Use of a full-size core allowed evaluating the effectiveness of METKA technology. The technology allowed to involve in the development low-permeability reservoirs and reservoirs that were not flooded. Study showed that results of standard-size core models are not informative to evaluate flooding efficiency.

For the conditions of complex carbonate reservoirs due to low representation of standard samples the need to use core samples of maximal diameter is determined. Results obtained have practical importance in correct determination of parameters for EOR application during field development.

Приведен анализ влияния размера керновых образцов на достоверность данных, получаемых в ходе лабораторного моделирования технологий воздействия на пласт в зависимости от типа коллекторов.

Определено, что, в отличие от составных моделей, полноразмерный керн максимально полно отражает взаимосвязь поровых систем сложнопостроенных коллекторов, что позволяет делать более корректные выводы об эффективности технологий, в частности, определять адсорбцию и механическую деструкцию полимерных составов, прочность созданного водоизоляционного барьера, динамику давления в процессе закачки составов и т.д. При подборе полноразмерных образцов керна с целью повышения достоверности полученных результатов при лабораторном моделировании необходимо учитывать анизотропию пород, которая присуща карбонатным коллекторам и, как правило, связана с трещиноватостью пород.

На основании сформированных представлений о повышении эффективности моделирования технологий повышения нефтеотдачи пластов (ПНП) для условий сложнопостроенных карбонатных коллекторов проведены лабораторные исследования с использованием кернового материала на примере испытаний термообратимой полимерной ные исследования с использованием кернового материала на примере испытаний термообратимой полимерной композиции «МЕТКА», разработанной Институтом химии нефти Сибирского отделения Российской академии наук. Использование полноразмерного керна позволило оценить эффективность технологии «МЕТКА» при вовлеченных или слабо охваченных заводнением. Проведение исследований составных моделей из керна стандартного размера показало неинформативность полученных результатов для оценки охвата заводнением.

Определена необходимость использования керновых образцов максимального диаметра при проведении испытаний для условий сложнопостроенных карбонатных коллекторов ввиду низкой представительности стандартных образцов. Полученные результаты имеют практическое значение для корректного определения параметров реализации технологий ПНП на скважинах при разработке месторождений.

Ivan S. Putilov (Author ID in Scopus: 25723777700) - PhD in Engineering, Deputy Director for Science in Geology (tel.: +007 342 233 64 58, e-mail: Ivan.Putilov@pnn.lukoil.com).

Pavel N. Rekhachev (Author ID in Scopus: 56088245400) - Head of the Centre of Core and Reservoir Fluid Study (tel.: +007 342 233 6441 , e-mail: Pavel.Rehachev@pnn.lukoil.com).

Irina P. Gurbatova (Author ID in Scopus: 55536701100) - PhD in Engineering, Deputy Head of the Centre of Core and Reservoir Fluid Study (tel. +007 3422336493 , e-mail: Irina.Gurbatova@pnn.lukoil.com).

Nikolai N. Barkovskii - Head of the Department of Study of Enhanced Oil Recovery Methods on Core (tel.: +007 3422336493 , e-mail: Nikolaj.Barkovskij@ pnn.lukoil.com). The contact person for correspondence.

Oleg I. Iakimov - Head of the Laboratory for Chemical Enhanced Oil Recovery Methods (tel.: +007 34271701 55, e-mail: Oleg.Jakimov@pnn.lukoil.com).

Oleg A. Moroziuk (Author ID in Scopus: 56006963800) - PhD in Engineering, Associate Professor at the Department of Development and Exploitation of Oil and Gas Fields and Underground Hydromechanics (tel.: +007 821677 44 75, e-mail: zav_rangm@ugtu.net).

Путилов Иван Сергеевич - кандидат технических наук, заместитель директора по научной работе в области геологии (тел.: +007 3422336458 , e-mail: Ivan.Putilov@pnn.lukoil.com).

Рехачев Павел Николаевич - начальник центра исследования керна и пластовых флюидов (тел.: +007 342 233 64 41, e-mail: Pavel.Rehachev@pnn.lukoil.com). Рехачев Павел Николаевич - начальник центра исследования керна и пластовых флюидов (тел.: +007 34223364 и, e-mail: Pavel.Rehachev@pnn.lukoil.com).
Гурбатова Ирина Павловна - кандидат технических наук, заместитель начальника центра исследования керна и пластовых флюидов (тел. +007 342 233 6493 ,
e-mail: Irina.Gurbatova@pnn.lukoil.com).

Барковский Николай Николаевич - начальник отдела исследования методов повышения нефтеотдачи пласта на керне (тел.: +007 3422336493 , e-mail: Nikolaj.Barkovskij@pnn.lukoil.com). Контактное лицо для переписки.

Якимов Олег Игоревич - заведующий лабораторией химических методов повышения нефтеотдачи пластов (тел.: +007 3427170155 , e-mail: Oleg.Jakimov@ pnn.lukoil.com).

Морозюк Олег Александрович - кандидат технических наук, доцент кафедры разработки и эксплуатации нефтяных и газовых месторождений и подземной гидромеханики (тел.: +007 82167744 75, e-mail: zav_rangm@ugtu.net). 


\section{Introduction}

Uneven recovery of reserves during development of oil fields and failure to achieve designed oil recovery factor require application of enhanced oil recovery methods (EOR). One of the most common methods of EOR is injectivity profile alignment method of injection wells. The main purpose of injectivity profile alignment is to increase water flooded zone across the reservoir thickness, flooded area and redistribution of injection volumes between layers and interlayers under simultaneous influence on replacement agents. Treatments are done with use of temporary insulating materials: gelling mixtures, emulsions, sediment-solutions, water solutions of poliacrylamide etc. Deterioration of geological and physical characteristics and technological parameters of well operation limit the field of application of existing stimulation methods, which leads to the need to find and implement new technologies.

Special attention in the selection of EOR technologies should be given to laboratory research stage, in particular fluid flow in a core. That allows assessing visually the effectiveness of technology of interest. Wrong conclusions at the stage of laboratory simulation can either to discredit a highly effective method or cause large material costs during implementation of industrial-scale inefficient EOR method [1].

To improve authenticity of results obtained during simulation of EOR technologies on the stage of fluid flow following features have to be considered: geological structure of a field, structure of rocks, which is a reason for qualitative selection of adequate reservoir model.

\section{Impact analysis of core sample size on the authentic of the data obtained during the study of EOR technologies}

In accordance with existing views, core samples that model reservoir sections of technology influence, should have properties of statistical representation from the point of view of reservoir. This situation is possible only under the condition that studied core contains a large number of ele- ments making up the formation that their common behavior in the formation and in the studied core will be identical [2].

For clastic reservoirs presented by porous type of voids flow of reservoir fluids and injected agents in full-size samples $(100 \times 100 \mathrm{~mm})$ and in standard samples $(30 \times 30 \mathrm{~mm})$ is done through the similar channel system.

For complex carbonate reservoirs with naturally fractured, porous and cavities type it is not so an unambiguous. They are characterized by a complex multimodal nature of the void size distribution [2-4]. Structure of void space of carbonate reservoir in a general case can be considered as a system of major voids (caverns, large cracks, pockets of large voids), communicating through a system of smaller voids (micro cracks, small voids) (Fig. 1).

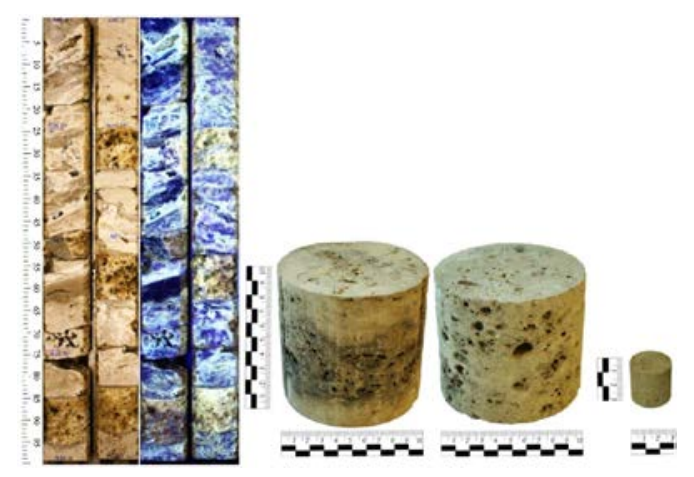

Fig. 1. Core samples of different size

Fig. 1 illustrates a direction of full-size core void system, while the permeability of a standard sample depends on the point of cutting out (Fig. 2).

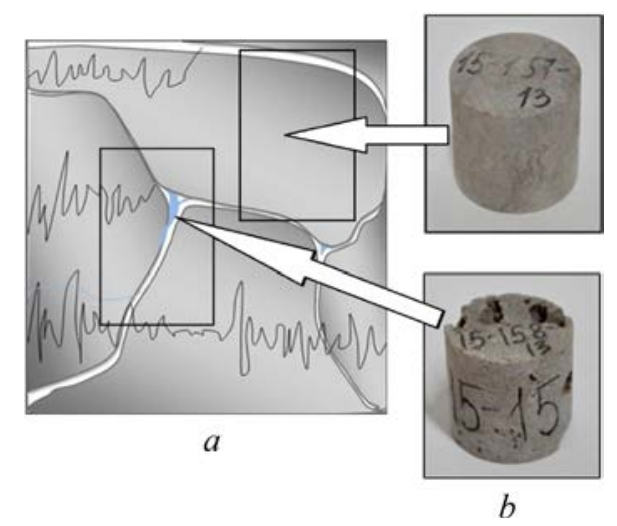

Fig. 2. Distribution of void system in core samples: $a$ - full-size core sample; $b$ - standard core sample 
Void volume of standard sample size is $\approx 20.9 \mathrm{~cm}^{3}$, full-size core $\approx 785.4 \mathrm{~cm}^{3}$. Thus, volume of full-size $10 \mathrm{~cm}$ sample is 37.5 times larger than a standard one therefore representation of obtained results is significantly higher. In order to increase void space it is possible to create models that consist of several standard core samples. However, due to the high inhomogeneity of carbonate reservoir, difference of permeability values of standard samples cut from the same full-size core can be several orders of magnitude.

Unlike composite models a full-sized core fully reflects the relationship of void systems of complex reservoirs that allows to make more valid conclusions on the effectiveness of technologies, in particular, the determination of adsorption and mechanical destruction of polymer compositions, strength of created water proofing barrier, injection pressure dynamics etc. In the selection of full-size core samples in order to improve the reliability of the results obtained in the laboratory simulation, it is necessary to take into account the anisotropy of the rock, which is inherent in carbonate reservoirs and usually connected with fractured rocks [5-12].

\section{Implementation of developed approach to model EOR technologies on example of simulation test of METKA technology}

Based on ideas about improved EOR technology modeling effectiveness for conditions of complex carbonate reservoirs PermNIPIneft branch of of LUKOIL-Engineering LLC in Perm conducted laboratory tests using core samples. This approach is implemented in the framework of fluid flow tests with new thermo polymer composition METKA developed by the Institute of Petroleum Chemistry of Siberian Branch of the Russian Academy of Science for the field of TimanPechora oil and gas province, characterized by complex reservoir.

The technology is aimed to improve sweep efficiency in water flooding, thermal, steam and cyclic steam stimulation and limitation of water production, by injection through water, steam, cyclic steam or production wells of water solutions of METKA composition. That is capable to form thermo reversible polymer gels in situ. A factor that causes reversible phase transition solution-gel is a thermal energy of reservoir or injected heating agent. Gels formed in the formation inhibit breakthrough of water or steam from injection to production wells. They redistribute reservoir fluid flow in oil formation that leads to stabilization or reduction of water cut of near production or cyclic steam wells and enhanced oil recovery [13-14].

Technology principle is illustrated in Fig. 3.

Due to high heterogeneity of reservoir properties studies are performed on two-layer model on objects of pilot project. Each model consisted of two parallel full-size core samples $(110 \mathrm{~mm}$ in length and diameter), simulating low permeable and high permeable interlayers (Fig. 4).

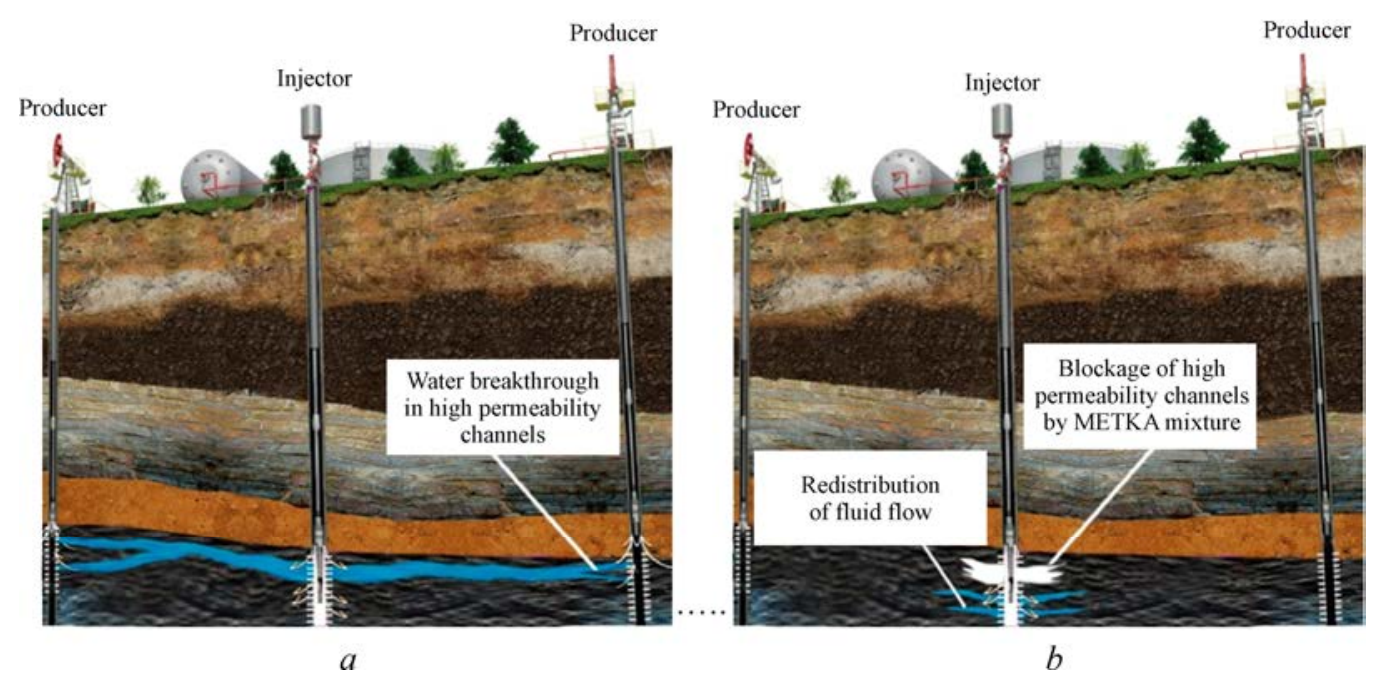

Fig. 3. Technology principle: $a$ - before METKA composition injection; $b$ - after METKA composition injection 


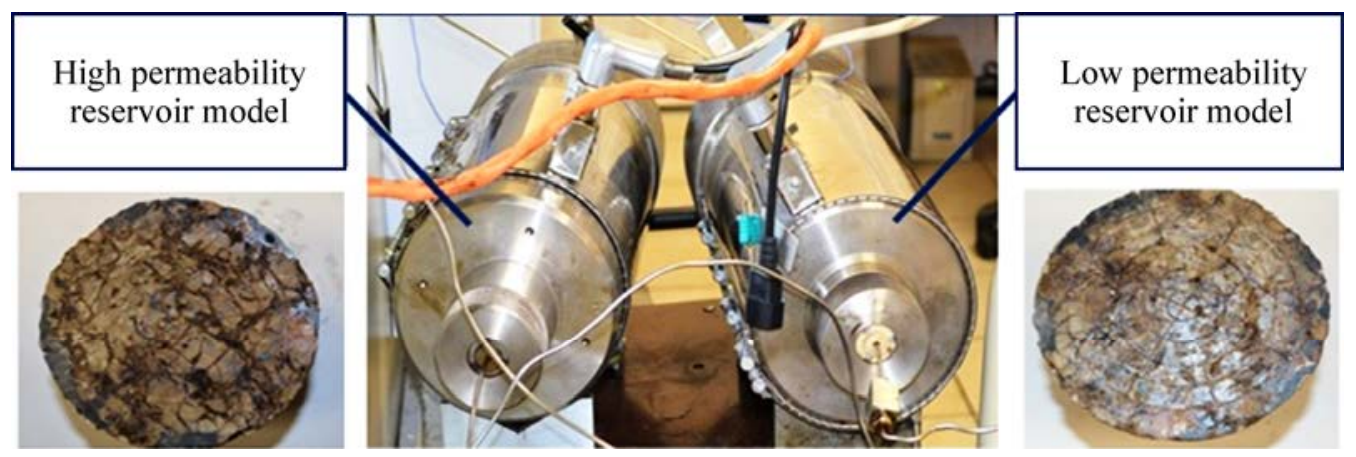

Fig. 4. General view of two-layer reservoir model

During operation works ability of technology to redistribute fluid flows under the conditions of expected temperature $\left(50\right.$ and $\left.100{ }^{\circ} \mathrm{C}\right)$ and efficiency of composition at high temperatures $\left(200^{\circ} \mathrm{C}\right)$ are determined.

At the initial stage research was done in "free volume" with selection of an optimal METKA composition [15-19].

Workflow of fluid flow test:

- to create an initial oil saturation of core models in accordance with OST 39-195-86 [20];

- to displace oil by pressure maintenance water flow through the two-layer model (simulation of initial flooding);

- to inject METKA composition in the amount of 0.5 of $V_{\text {por }}$ at the rate of $1.0 \mathrm{~cm}^{3} / \mathrm{min}$;

- to wait for 24 hours for maturation of mixture in the rock (determined by the results of preliminary studies in "free volume");

- to flow pressure maintenance fluid after mixture treatment;

- to calculate a coefficient of displacement of oil by water $K_{\text {disp }}$ and residual factor for water resistance $R R F_{w}$.

During the experiments pressure drops, volumes and time of pumping of fluid flow were recorded.

Study results are shown in the Table 1 . Pressure dynamics and oil displacement coefficients are shown in Fig. 5.

As a result of the fluid flow tests of METKA mixture on two-layer core models change in the coefficient of oil displacement by water is recorded. Values of the main indicators are presented in Table 2.
It is determined during fluid flow test that the main addition is related to oil displaced from low permeability samples by aligning the profile of injected water and redistribution of fluid flows to non-drained reservoir areas. Besides, addition oil is dedicated to its displacement from high permeability samples due to blockage of drained channels and involvement into fluid flow previously not drained areas.

Thus, stated effects of the technology that block high permeability with high water cut and redistribute fluid flow of injected water into lower permeability reservoir areas are proved. Noted that the mixture showed its efficiency at both low $\left(50^{\circ} \mathrm{C}\right)$ and high temperatures $\left(100,200{ }^{\circ} \mathrm{C}\right)$.

To determine need to use maximum diameter core samples in the tests for the conditions of complex carbonate reservoirs, METKA technology was studied using two-layer model, consisting of a standard size sample $(3 \times 3 \mathrm{~cm})$. Standard core models study carried out on analog workflow at temperature of $50^{\circ} \mathrm{C}$.

Comparative characteristics of study of full-size and standard core models are presented in Table 3.

Table 3 shows that at the stage of the test beginning determination of results of $K_{\text {disp } 1}$ study (before mixture injection) on full-size samples $\left(K_{\text {disp1 }}=0.21\right.$ unit fracture $)$ are closer to design values of oil recovery factor (ORF $=0.15$ unit fracture) than standard samples $\left(K_{\text {disp1 }}=0.292\right.$ unit fracture). 


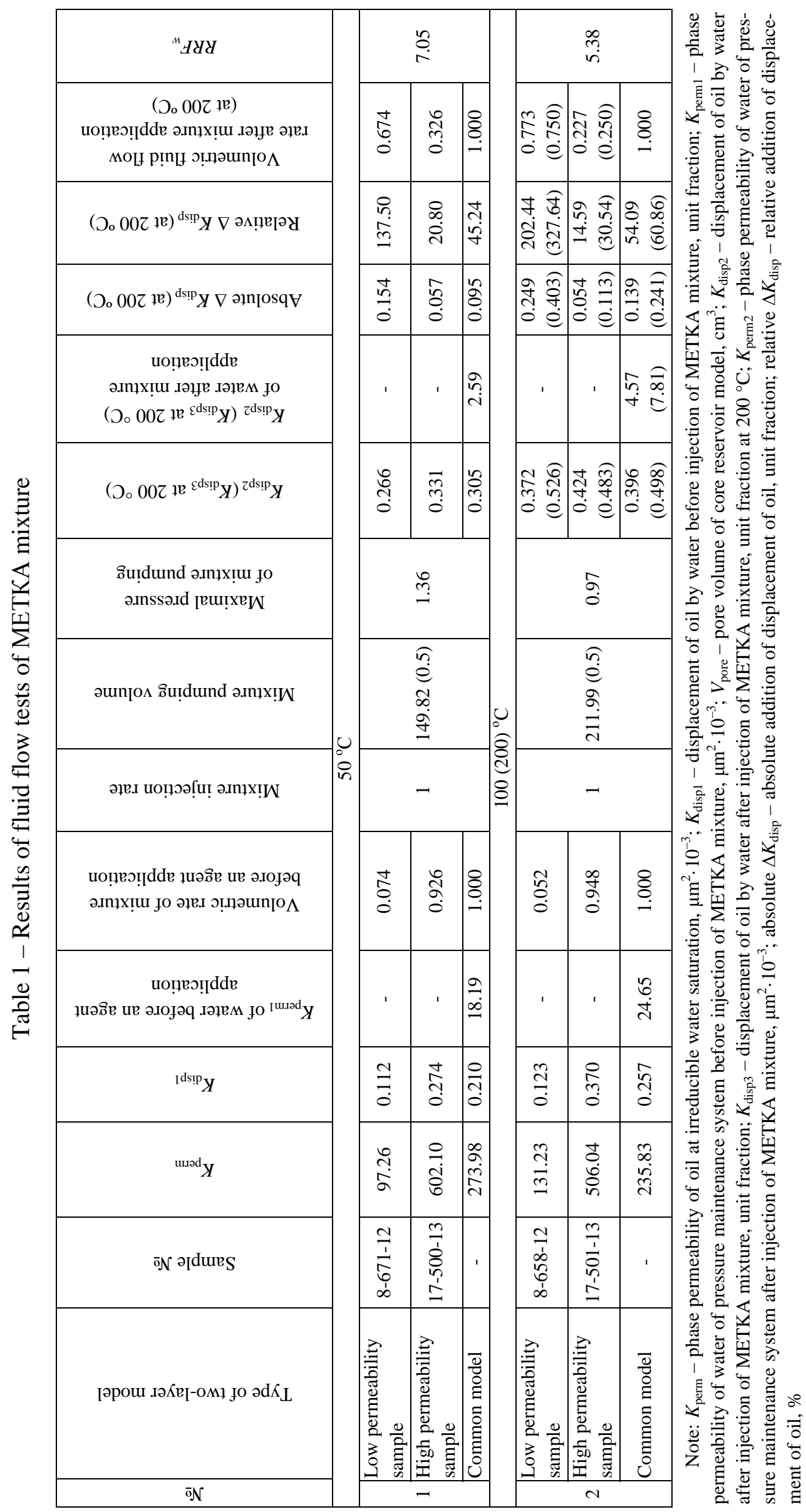



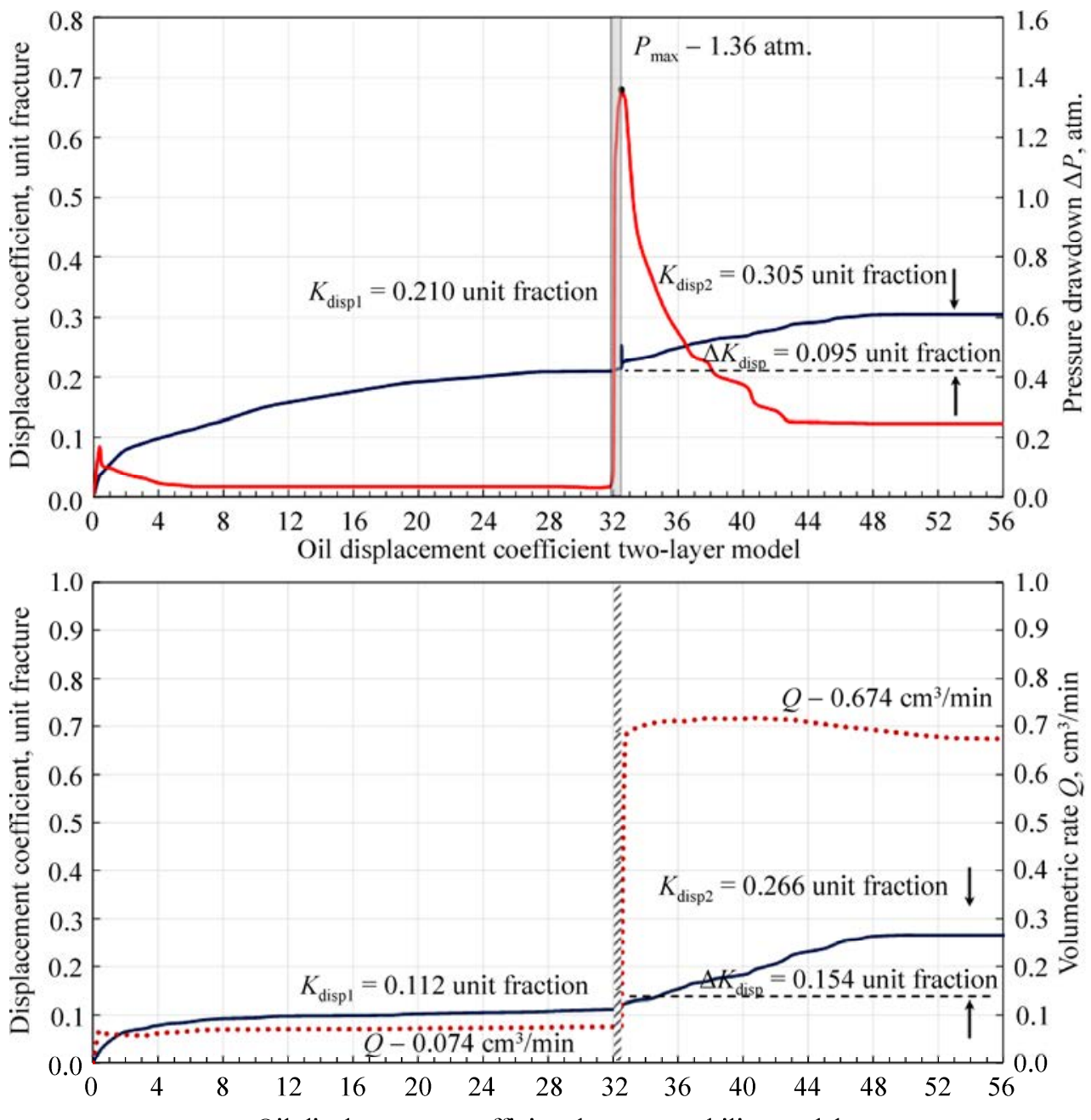

Oil displacement coefficient low permeability model

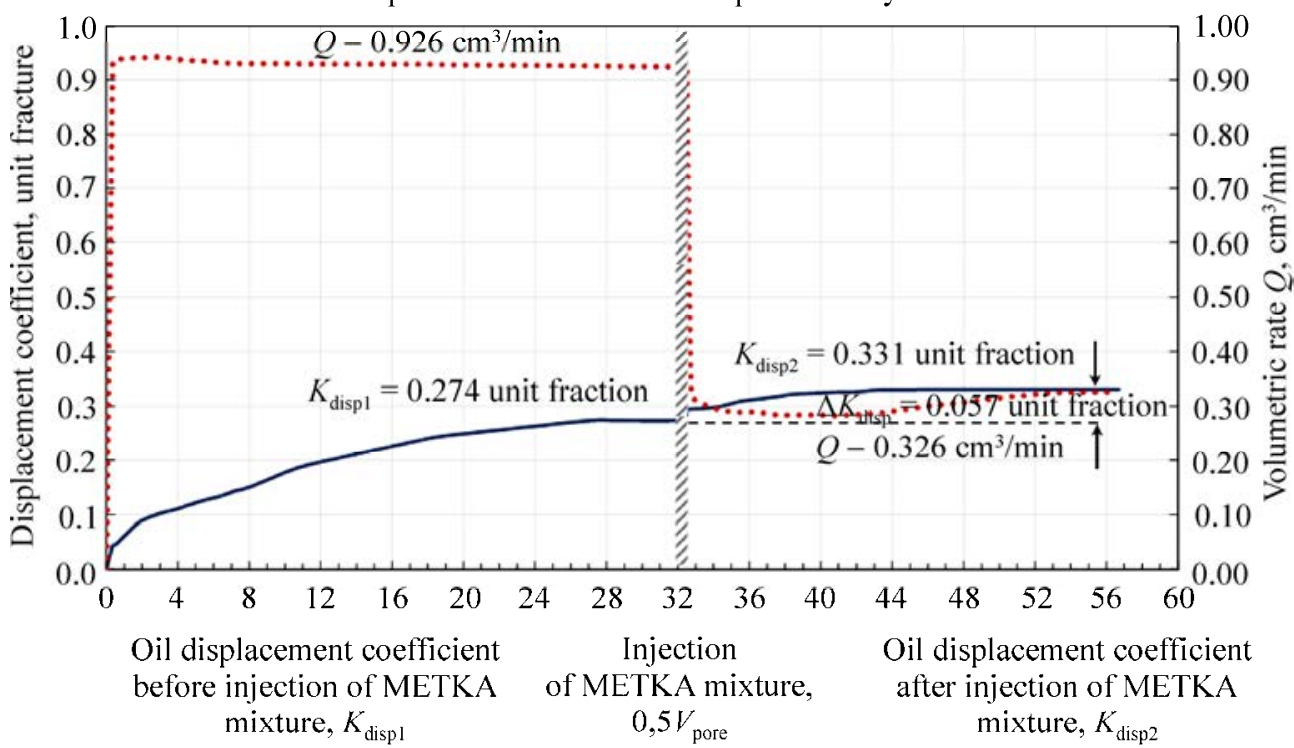

Oil displacement coefficient high permeability model

Volume of pumped liquid to general pore volume of two-layer model, $V_{\text {liquid }} / V_{\text {pore }}$

Fig. 5. Dynamics of main indicators of displacement on two-layer model $\left(50^{\circ} \mathrm{C}\right)$ 
Table 2 - Results of fluid flow tests of METKA mixture on two-layer model

\begin{tabular}{|c|c|c|c|c|c|c|c|c|c|}
\hline $\begin{array}{l}\mathrm{T}, \\
{ }^{\circ} \mathrm{C}\end{array}$ & № & Model type & $\begin{array}{l}K_{\text {disp 1, }} \\
\text { unit } \\
\text { fraction }\end{array}$ & \begin{tabular}{|c|} 
Distribution of \\
volumetric rate before \\
mixture application, \\
$\%$
\end{tabular} & $\begin{array}{l}R R F_{w} \\
\text { unit } \\
\text { fraction }\end{array}$ & \begin{tabular}{|c|} 
Distribution of \\
volumetric rate after \\
mixture application, \\
$\%$
\end{tabular} & $\begin{array}{c}K_{\text {disp2, }} \\
\text { unit } \\
\text { fraction }\end{array}$ & $\begin{array}{c}\text { Absolute } \\
\Delta K_{\text {disp }}, \\
\text { unit fraction }\end{array}$ & $\begin{array}{l}\text { Relative } \\
\Delta K_{\text {disp }}, \\
\%\end{array}$ \\
\hline \multirow{2}{*}{50} & \multirow{2}{*}{1} & Low permeability & \multirow{2}{*}{0.210} & 7.4 & 7.02 & 67.4 & \multirow{2}{*}{0.305} & \multirow{2}{*}{0.095} & \multirow{2}{*}{45.24} \\
\hline & & High permeability & & 92.6 & & 32.6 & & & \\
\hline \multirow{2}{*}{100} & \multirow{4}{*}{2} & Low permeability & \multirow{2}{*}{0.257} & 5.2 & \multirow{2}{*}{5.38} & 77.3 & \multirow{2}{*}{0.396} & \multirow{2}{*}{0.139} & \multirow{2}{*}{54.09} \\
\hline & & High permeability & & 94.8 & & 22.7 & & & \\
\hline \multirow{2}{*}{200} & & Low permeability & \multirow{2}{*}{0.396} & 77.3 & \multirow{2}{*}{ - } & 75.0 & \multirow{2}{*}{0.498} & \multirow{2}{*}{0.102} & \multirow{2}{*}{25.76} \\
\hline & & High permeability & & 22.7 & & 25.0 & & & \\
\hline
\end{tabular}

Table 3 - Main parameters of fluid flow tests of METKA composition on full-size and standard core models at $50{ }^{\circ} \mathrm{C}$

\begin{tabular}{|c|c|c|c|c|c|c|c|c|c|c|}
\hline № & Model type & $\begin{array}{c}K_{\text {perm }} \\
\text { of oil, } \\
\mu \mathrm{km}^{2} \cdot 10^{-3}\end{array}$ & $\begin{array}{c}K_{\text {perm1 }} \text { of } \\
\text { water before } \\
\text { mixture } \\
\text { application, } \\
\text { mD }\end{array}$ & $\begin{array}{c}K_{\text {disp1, }} \\
\text { unit } \\
\text { frac- } \\
\text { tion }\end{array}$ & $\begin{array}{c}\text { Distribution } \\
\text { of volumetric rate } \\
\text { before mixture } \\
\text { application, \% }\end{array}$ & $\begin{array}{l}R R F_{w}, \\
\text { unit } \\
\text { fraction }\end{array}$ & $\begin{array}{c}\text { Distribution } \\
\text { of volumetric rate } \\
\text { after mixture } \\
\text { application, \% }\end{array}$ & $\begin{array}{l}K_{\text {disp 2, }} \\
\text { unit } \\
\text { fraction }\end{array}$ & $\begin{array}{c}\text { Absolut } \\
\text { e } \Delta K_{\text {disp }} \\
\text { unit } \\
\text { fraction }\end{array}$ & $\begin{array}{c}\text { Relative } \\
\Delta K_{\text {disp}}, \\
\%\end{array}$ \\
\hline \multicolumn{11}{|c|}{ Full-size core model } \\
\hline & Low permeability & 97.26 & \multirow{3}{*}{18.19} & 0.112 & 7.4 & \multirow{3}{*}{7.02} & 67.4 & 0.266 & 0.154 & 137.50 \\
\hline \multirow[t]{2}{*}{1} & High permeability & 602.10 & & 0.274 & 92.6 & & 32.6 & 0.331 & 0.057 & 20.80 \\
\hline & Common model & 273.98 & & 0.210 & 100.0 & & 100.0 & 0.305 & 0.095 & 45.24 \\
\hline \multicolumn{11}{|c|}{ Standard core sample model } \\
\hline \multirow{3}{*}{2} & Low permeability & 86.56 & \multirow{3}{*}{16.28} & 0.260 & 7.4 & \multirow{3}{*}{10.86} & 88.3 & 0.315 & 0.055 & 21.15 \\
\hline & High permeability & 585.33 & & 0.327 & 92.6 & & 11.7 & 0.327 & 0 & 0 \\
\hline & Common model & 253.75 & & 0.292 & 100.0 & & 100.0 & 0.320 & 0.028 & 9.59 \\
\hline
\end{tabular}

Besides, during subsequent determination of $K_{\text {disp2 }}$ (after mixture injection):

1) in comparison with full-size core standard one did not show oil displacement from high permeability model; the mixture blocked almost full flow channels of core samples which represent a major part of pore space;

2) the standard model has much lower addition oil $\left(\Delta K_{\text {disp }}\right)$ in low permeability area (0.055 unit fracture) than analog model of fullsize core ( 0.154 unit fracture). These differences are explained by low values of pore volume of standard low permeability samples, which led to their significant flooding in initial flooding modeling process.

As a result, data on the growth rate of displacement after the application of METKA composition on models consisting of standard samples compared with obtained on full-size cores are underestimated several times.

\section{Conclusion}

Thus, performed analysis revealed that during the study of carbonate reservoirs of complex structure due to its low authenticity of standard samples in terms of link between pore systems (proved by the results of METKA technology study) there is a need to use core samples of maximal diameter

Use of full-size core in laboratory simulations allowed estimating efficiency of the technology during involvement into drainage both low permeability and high permeability zones that were not involved into flooding previously.

Results obtained have practical importance in correct determination of parameters for EOR application during field development. 


\section{References}

1. Gazizov A.A. Uvelichenie nefteotdachi neodnorodnykh plastov na pozdnei stadii razrabotki [Enhanced oil recovery of heterogeneous reservoirs at a late stage of development]. Moscow: Nedra-Biznestsentr, 2002. 639 p.

2. Mikhailov N.N., Gurbatova I.P. Masshtabnyi effekt pri laboratornom opredelenii fil'tratsionnoemkostnykh svoistv slozhnopostroennykh karbonatnykh kollektorov [Scale effect at laboratory determination of permeability and porosity properties of complex structured carbonate reservoirs]. Oil and Gas Technologies, 2011, no.4, pp.32-36.

3. Mikhailov N.N., Gurbatova I.P. Analiz informativnosti opredelenii emkostnykh svoistv plasta dlia podscheta zapasov nefti i gaza [Analysis of informativeness determination of reservoir properties for avaluation of oil and gas reserves]. Novye tekhnologii osvoeniia i razrabotki trudnoizvlekaemykh zapasov nefti i gaza i povysheniia nefteotdachi: trudy VII mezhdunarodnogo simpoziuma. Moscow, 2008. Pp.184-192.

4. Gurbatova I.P., Mikhailov N.N. Analiz informativnosti razlichnykh metodik opredeleniia emkostnykh svoistv karbonatnykh plastov so slozhnym tipom poristosti [Analysis of the information content of different methods for determination of reservoir properties of carbonate reservoirs with a complex type of porosity]. Vestnik TsKR Rosnedra, 2008, no.2, pp.52-56.

5. Kuz'min V.A., Maksimov V.M., Mikhailov N.N., Gurbatova I.P. Eksperimental'noe issledovanie mikrostrukturnykh osobennostei proiavleniia anizotropii karbonatnykh kollektorov [Pilot study of microstructure peculiarities of appearance of carbonate reservoir anisotropy]. Vestnik TsKR Rosnedra, 2011, no.4, pp.39-47.

6. Merkulov V.P., Krasnoshchekova L.A., Aleksandrov D.V., Martynova T.E. Issledovanie anizotropii kollektorov neftianykh mestorozhdenii [Research of anisotropy of oil reservoirs]. Sbornik tezisov dokladov 9 mezhdunarodnoi nauchnoprakticheskoi konferentsii «Geomodel'-2007», Gelendzhik, 16-21 sentiabria 2007. Moscow: ЕАГЕ, 2007. pp.55.
7. Al'vard A.A., Zainutdinov R.S. Anizotropiia pronitsaemosti gornykh porod kollektorov i ee rol' $\mathrm{v}$ regulirovanii protsessov razrabotki [Anisotropy of reservoirs rock permeability and its role in development processes regulation]. Interval, 2003, no.9 (56), pp.26-31.

8. Krasnoshchekova L.A., Merkulov V.P. Petrofizicheskaia neodnorodnost' neftenosnykh kollektorov Igol'sko-Talovogo mestorozhdeniia (Tomskaia oblast') [Petrophysical heterogeneity of the oil-bearing formations belonging to the Igolsko-Talovskoye field (Tomsk region)]. Neftegazovaya geologiya. Teoriya i praktika - Petroleum Geology - Theoretical and Applied Studies, 2014, vol.9, no.2.

9. Bandiziol D., Massonat G. Horizontal permeability anisotropy characterization by pressure transient testing and geological data. SPE paper 24667. 67th Annual Technical Conference and Exhibition of the Society of petroleum Engineers. October 4-7, 1992. Washington D.C., 1992. Pp.39-52.

10. Hidayati D.T., Chen H.Y., Teufel L.W. The reliability of permeability-anisotropy estimation from interference testing of naturally fractured reservoirs. SPE Paper 59011. International Petroleum Conference and Exhibition in Mexico. Villahemosa, Mexico, Feb. 1-3, 2000. 13 p.

11. Wade J.M., Hough E.V., Pedersen S.H. Practical methods employed in determining permeability anisotropy for optimization of a planned waterflood of the eldfisk field. SPE Paper 48961. Annual Technical Conference and Exhibition. New Orleans, USA, September 27-30, 1998. 36 p.

12. Al-Hadrami H.K., Teufel L.W. Influence of permeability anisotropy and reservoir heterogeneity on optimization of infill drilling in naturally fractured tight-gas mesaverde sandstone reservoirs, San Juan Basin. SPE Paper 60295. Rocky Mountain Regional. Low Permeability Reservoirs Simposium. Denver, USA, March 12-15, 2000. 12 p.

13. Altunina L.K., Kuvshinov V.A., Stas'eva L.A. Termoobratimye polimernye geli dlia uvelicheniia nefteotdachi [Thermoreversible polymer gels for enhanced oil recovery]. Khimiia $v$ interesakh ustoichivogo razvitiia, 2011, no.19, pp.127-136. 
14. Altunina L.K., Kuvshinov V.A., Stasyeva L.A. et al. Thermoreversible polymer gels for EOR. Proc. 9th Europe an Symposium on Improved Oil Recovery. The Haque, Netherlands, October, 20-22, 1997. Pp. 205.

15. Shramm G. Osnovy prakticheskoi reologii i reometrii [Basics of practical rheology and rheometry]: perevod s angliiskogo. Moscow: KolosS, 2003. 312 p.

16. Cherepanova N.A., Galimov I.M. Reologiia i fil'tratsionnye svoistva sshitykh polimernykh gidrogelei [The rheology and fluid flow properties of the crosslinked polymeric hydrogels]. Interval, 2002, no.1, pp.40-43.

17. Vinogradov G.V., Malkin A.Ia. Reologiia polimerov [Polymer rheology]. Moscow: Khimiia, 1977. $440 \mathrm{p}$.
18. API RP 63-1990. Recommended practices for evaluation of polymers used in enhanced oil recovery operations first edition. Washington D.C., 2005. P.86.

19. GOST 1929-1987. Nefteprodukty. Metody opredeleniia dinamicheskoi viazkosti na rotatsionnom viskozimetre [Petroleum products. Methods for determination of dynamic viscosity at a rotary viscometer], available at: http:// www.vashdom.ru/ gost/1929-87/

20. OST 39-195-86. Neft'. Metod opredeleniia koeffitsienta vytesneniia nefti vodoi v laboratornykh usloviiakh [Oil. Method of determining the coefficient of oil displacement by water in the laboratory], available at: http://meganorm.ru/Index2/ 1/4293836/4293836586.htm

\section{Список литературы}

1. Газизов А.А. Увеличение нефтеотдачи неоднородных пластов на поздней стадии разработки. - М.: Недра-Бизнесцентр, 2002. - 639 с.

2. Михайлов Н.Н., Гурбатова И.П. Масштабный эффект при лабораторном определении фильтрационно-емкостных свойств сложнопостроенных карбонатных коллекторов // Технологии нефти и газа. - 2011. - № 4. - С. 32-36.

3. Михайлов Н.Н., Гурбатова И.П. Анализ информативности определений емкостных свойств пласта для подсчета запасов нефти и газа // Труды VII международного симпозиума «Новые технологии освоения и разработки трудноизвлекаемых запасов нефти и газа и повышения нефтеотдачи». М., 2008. - C. 184-192.

4. Гурбатова И.П., Михайлов Н.Н. Анализ информативности различных методик определения емкостных свойств карбонатных пластов со сложным типом пористости // Вестник ЦКР Роснедра. - 2008. - № 2. - С. 52-56.

5. Экспериментальное исследование микроструктурных особенностей проявления анизотропии карбонатных коллекторов / В.А. Кузьмин, В.М. Максимов, Н.Н. Михайлов, И.П. Гурбатова // Вестник ЦКР Роснедра. - 2011. - № 4. - С. 39-47.

6. Исследование анизотропии коллекторов нефтяных месторождений / В.П. Меркулов, Л.А. Краснощекова, Д.В. Александров, Т.Е. Мар- тынова // Сборник тезисов докладов 9-й международной научно-практической конференции «Геомодель-2007», Геленджик, 16-21 сентября 2007. - М.: ЕАГЕ, 2007. - С. 55.

7. Альвард А.А., Зайнутдинов Р.С. Анизотропия проницаемости горных пород коллекторов и ее роль в регулировании процессов разработки // Интервал. - 2003. - № 9 (56). - С. 26-31.

8. Краснощекова Л.А., Меркулов В.П. Петрофизическая неоднородность нефтеносных коллекторов Игольско-Талового месторождения (Томская область) // Нефтегазовая геология. Теория и практика. - 2014. - Т. 9. - № 2.

9. Bandiziol D., Massonat G. Horizontal permeability anisotropy characterization by pres sure transient testing and geological data // SPE paper 24667. 67th Annual Technical Conference and Exhibition of the Society of petroleum Engineers, October 4-7, 1992. - Washington D.C., USA, 1992. - P. 39-52.

10. Hidayati D.T., Chen H.Y., Teufel L.W. The reliability of permeability-anisotropy estimation from interference testing of naturally fractured reservoirs // SPE Paper 59011. International Petroleum Conference and Exhibition in Mexico, Feb. 1-3 2000. - Villahemosa, 2000. - 13 p.

11. Wade J.M., Hough E.V., Pedersen S.H. Practical methods employed in determining 
permeability anisotropy for optimization of a planned waterflood of the eldfisk field // SPE Paper 48961. Annual Technical Conference and Exhibition, New Orleans, USA, September 27-30, 1998. - New Orleans, 1998. - 36 p.

12. Al-Hadrami H. K., Teufel L. W. Influence of permeability anisotropy and reservoir heterogeneity on optimization of infill drilling in naturally fractured tight-gas mesaverde sandstone reservoirs, san juan basin // SPE Paper 60295, Rocky Mountain Regional. Low Permeability Reservoirs Simposium, Denver, USA, March 12-15, 2000. - Denver, 2000. - 12 p.

13. Алтунина Л.К., Кувшинов В.А., Стасьева Л.А. Термообратимые полимерные гели для увеличения нефтеотдачи // Химия в интересах устойчивого развития. - 2011. № 19. - С. 127-136.

14. Thermoreversible polymer gels for EOR / L.K. Altunina, V.A. Kuvshinov, L.A. Stasyeva et al. // Proc. 9th Europe an Symposium on Improved Oil Recovery. The Haque, Netherlands, October 20-22, 1997. - Haque, 1997. - P. 205.
15. Шрамм Г. Основы практической реологии и реометрии: пер. с англ. - М.: КолосС, 2003. - $312 \mathrm{c}$.

16. Черепанова Н.А., Галимов И.М. Реология и фильтрационные свойства сшитых полимерных гидрогелей // Интервал. - 2002. - № 1. C. 40-43.

17. Виноградов Г.В., Малкин А.Я. Реология полимеров. - М.: Химия, 1977. - 440 с.

18. API RP 63-1990. Recommended practices for evaluation of polymers used in enhanced oil recovery operations first edition. - Washington D.C., 2005. - C. 86.

19. ГОСТ 1929-1987. Нефтепродукты. Методы определения динамической вязкости на ротационном вискозиметре [Электронный pecypc]. - URL: http:// www.vashdom.ru/gost/192987/ (дата обращения: 24.12.2015).

20. ОСТ 39-195-86. Нефть. Метод определения коэффициента вытеснения нефти водой в лабораторных условиях [Электронный ресурс]. URL: http://meganorm.ru/Index2/1/4293836/4293 836586.htm (дата обращения: 24.12.2015)

Please cite this article in English as:

Putilov I.S., Rekhachev P.N., Gurbatova I.P., Barkovskii N.N., Iakimov O.I., Moroziuk O.A. Full-size core epoch at laboratory research of EOR technologies. Bulletin of PNRPU. Geology. Oil \& Gas Engineering \& Mining, 2016, vol.15, no.19, pp.155-164. DOI: 10.15593/2224-9923/2016.19.6

Просьба ссылаться на эту статью в русскоязычных источниках следующим образом:

Эпоха полноразмерного керна при лабораторных исследованиях технологий повышения нефтеотдачи пластов / И.С. Путилов, П.Н. Рехачев, И.П. Гурбатова, Н.Н. Барковский, О.И. Якимов, О.А. Морозюк // Вестник Пермского национального исследовательского политехнического университета. Геология. Нефтегазовое и горное дело. - 2016. - T.15, №19. - C.155-164. DOI: 10.15593/2224-9923/2016.19.6 